\title{
Teaching NeuroImages: Delayed nonischemic cerebral enhancing lesions post endovascular coil embolization
}

Margaret V. Bettin, MD, and Andrew M. Southerland, MD, MSc

Neurology ${ }^{\circledR}$ 2020;94:e2402-e2403. doi:10.1212/WNL.0000000000009537

Figure 1 Angiographic imaging

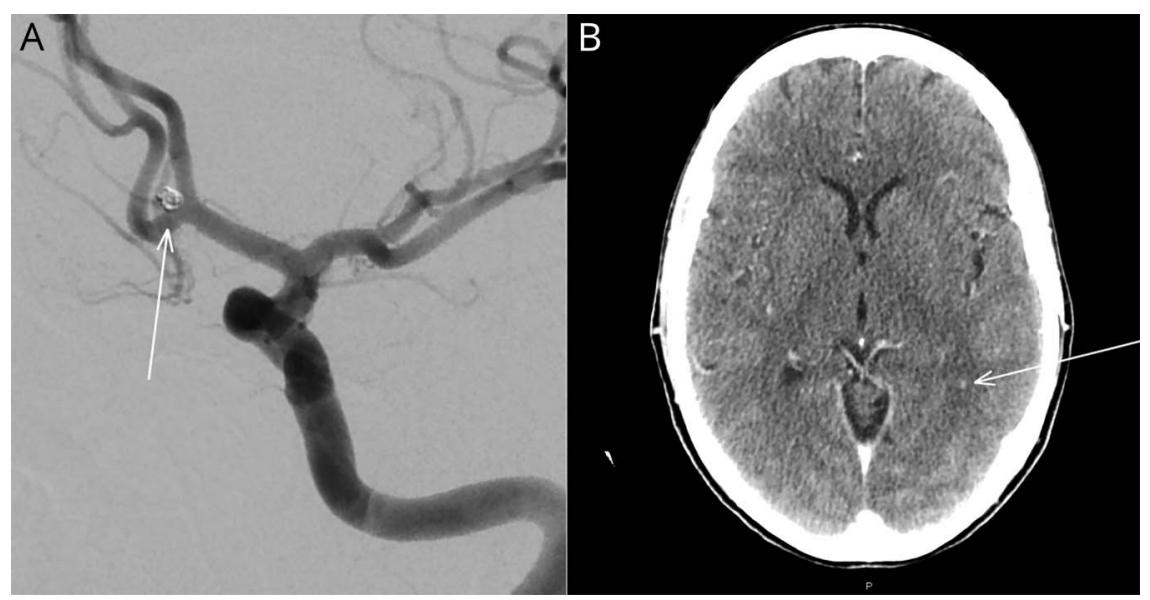

(A) Anterior communicating artery aneurysm post embolization using the penumbra SMART coil system (arrow). (B) CT angiography head with hyperdense lesion and surrounding edema noted in the left parietal white matter (arrow).

A 50-year-old woman underwent embolization of an anterior communicating artery aneurysm, via the left internal carotid artery, using the penumbra SMART coil system. Follow-up CT angiography at 16 months revealed a 2 -mm hyperdense lesion in the left parietal lobe (figure 1 ). MRI confirmed multiple punctate enhancing foci with surrounding edema favored to represent nonischemic cerebral enhancing (NICE) lesions (figure 2). NICE lesions are rare complications of coil embolization putatively associated with nickel allergy or coil emboli, ${ }^{1}$ although the SMART coil system is platinum based. The patient remained asymptomatic and further workup was withheld. Follow-up MRI at 1.5 months showed resolution.

\section{Study funding}

No target funding reported.

\section{Disclosure}

M. Bettin reports no relevant disclosures. A. Southerland is a past editor of the Neurology ${ }^{\circledR}$ podcast. Go to Neurology.org/N for full disclosures.
Correspondence

Dr. Southerland

as5ef@virginia.edu

\section{MORE ONLINE}

$\rightarrow$ Teaching Slides

links.lww.com/WNL/

B91. 

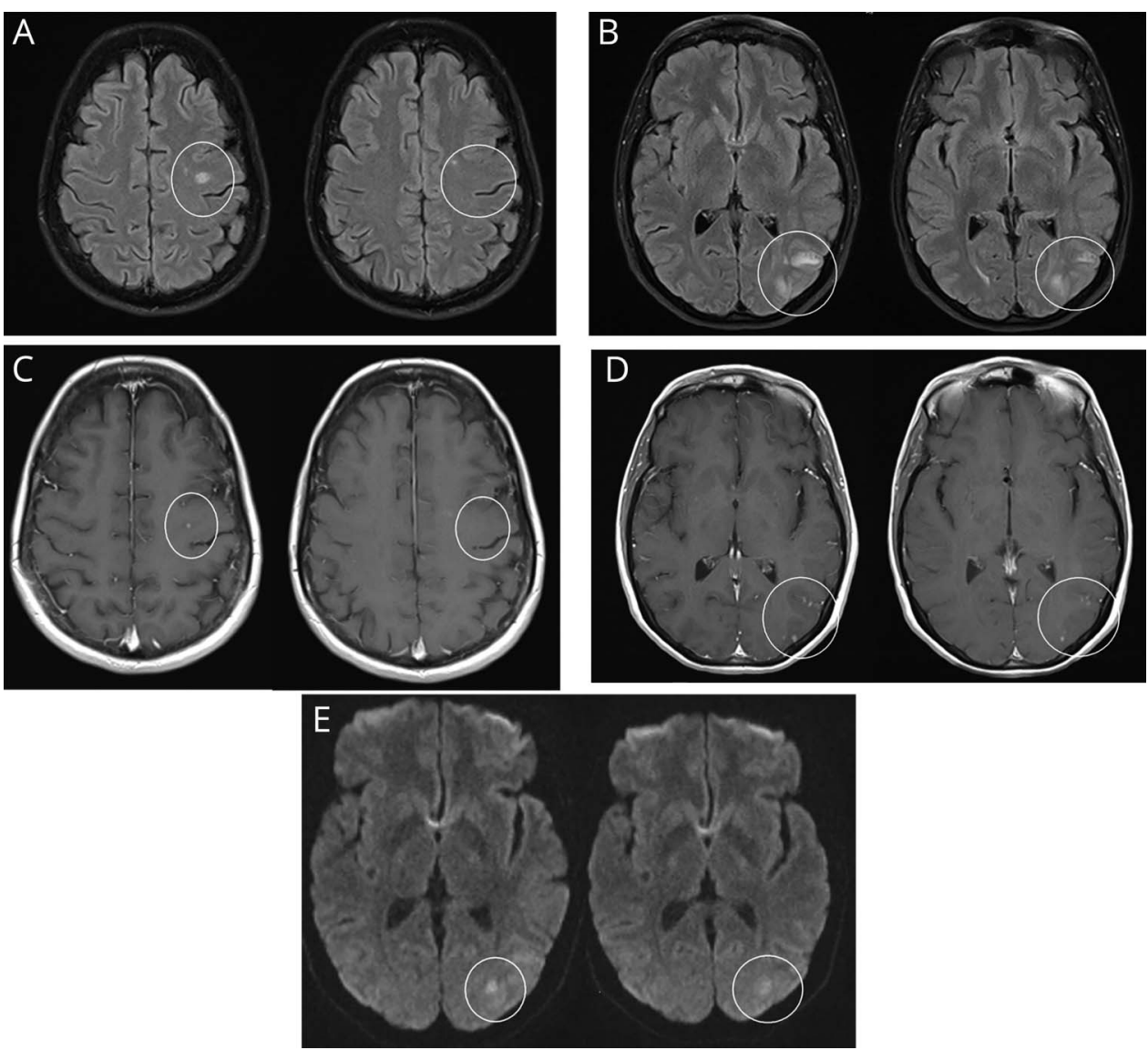

Each image (A-E) includes baseline imaging (left) with follow-up imaging 1.5 months later (right) demonstrating resolving lesions. (A, B) T2 fluidattenuation inversion recovery axial views encircling foci with vasogenic edema. (C, D) T1-weighted post contrast axial views encircling several 2-3 mm enhancing cortical and subcortical lesions in the left parieto-occipital lobe. (E) Axial diffusionweighted imaging encircling a small region of diffusion restriction.

\section{Appendix Authors}

\begin{tabular}{lll}
\hline Name & Location & Contribution \\
\hline $\begin{array}{l}\text { Margaret V. } \\
\text { Bettin, MD }\end{array}$ & $\begin{array}{l}\text { Department of } \\
\text { Neurology, University of } \\
\text { Virginia, Charlottesville }\end{array}$ & $\begin{array}{l}\text { Primary drafting and } \\
\text { revising of the manuscript }\end{array}$ \\
\hline $\begin{array}{l}\text { Andrew M. } \\
\text { Moutherland, MSc }\end{array}$ & $\begin{array}{ll}\text { Departments of } \\
\text { Neurology and Public } \\
\text { Health Sciences, } \\
\text { University of Virginia, } \\
\text { Charlottesville }\end{array}$ & $\begin{array}{l}\text { Conceptualization of the } \\
\text { study, acquisition and } \\
\text { interpretation of the data, } \\
\text { drafting and revising the } \\
\text { manuscript }\end{array}$ \\
\hline
\end{tabular}

\section{Reference}

1. Shotar E, Law-Ye B, Baronnet-Chauvet F, et al. Non-ischemic cerebral enhancing lesions secondary to endovascular aneurysm therapy: nickel allergy or foreign body reaction? Case series and review of the literature. Neuroradiology 2016;58:877-885. 


\section{Neurology}

\section{Teaching NeuroImages: Delayed nonischemic cerebral enhancing lesions post endovascular coil embolization}

Margaret V. Bettin and Andrew M. Southerland

Neurology 2020;94;e2402-e2403 Published Online before print May 1, 2020

DOI 10.1212/WNL.0000000000009537

This information is current as of May 1, 2020

\section{Updated Information \& Services}

References

Subspecialty Collections

Permissions \& Licensing

Reprints including high resolution figures, can be found at: http://n.neurology.org/content/94/22/e2402.full

This article cites 1 articles, 0 of which you can access for free at: http://n.neurology.org/content/94/22/e2402.full\#ref-list-1

This article, along with others on similar topics, appears in the following collection(s):

All Cerebrovascular disease/Stroke

http://n.neurology.org/cgi/collection/all_cerebrovascular_disease_strok e

Embolism

http://n.neurology.org/cgi/collection/embolism

Other cerebrovascular disease/ Stroke

http://n.neurology.org/cgi/collection/other_cerebrovascular_disease_s troke

Information about reproducing this article in parts (figures,tables) or in its entirety can be found online at:

http://www.neurology.org/about/about_the_journal\#permissions

Information about ordering reprints can be found online:

http://n.neurology.org/subscribers/advertise

Neurology ${ }^{\circledR}$ is the official journal of the American Academy of Neurology. Published continuously since 1951 , it is now a weekly with 48 issues per year. Copyright @ 2020 American Academy of Neurology. All rights reserved. Print ISSN: 0028-3878. Online ISSN: 1526-632X.

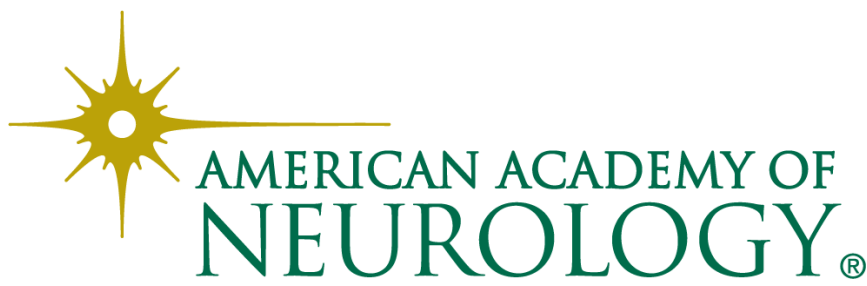

